\title{
A DESOFICIALIZAÇÃO DO ENSINO NO BRASIL: A REFORMA RIVADÁVIA
}

\author{
Carlos Roberto Jamil Cury ${ }^{*}$
}

\begin{abstract}
Liberta a consciência acadêmica da opressão dos mestres, arredada destes a tutela governamental, em cujo passivo se inscrevem todas as culpas da situação periclitante a que chegaram as instituiçóes do ensino, acredito dar um passo para frente com a atual organização. O que produzir o futuro cairá sob a responsabilidade das congregações. (Rivadávia Corrêa, na Exposição de Motivos da Lei Orgânica, in: Moacyr, 1942, p. 14)
\end{abstract}

\begin{abstract}
RESUMO: Esse texto pretende trazer à tona um momento bastante diferenciado de nossas reformas educacionais. Trata-se da Reforma Rivadávia, entre os anos de 1911-1915, levada a termo pelo Governo Federal. Por meio dela, o governo do presidente Hermes da Fonseca, tendo como seu ministro da Justiça o jurista Rivadávia Corrêa, ambos seguidores da doutrina positivista, buscaram o fim do status oficial do ensino. Baseando-se em uma interpretação discutível de um artigo da Constituição de 1891, o governo, por meio de um decreto presidencial, apoiado pelos parlamentares, determinou que as escolas de ensino secundário e de ensino superior perderiam os seus status de oficial e passariam a ser entidades corporativas autônomas. Com isso, o Estado perde a titularidade do monopólio da validade oficial dos diplomas e certificados e tal prerrogativa passa a ser dessas entidades. $\mathrm{O}$ ensino livre seria o remédio para os considerados maus catedráticos, para a contenção desenfreada de diplomas, de fraudes e de instalaçōes precárias dos estabelecimentos. Um conselho superior de
\end{abstract}

Doutor em Educação e professor do Programa de Pós-Graduação em Educação da Pontifícia Universidade Católica de Minas Gerais (PUC-Minas).E-mail: crjcury.bh@terra.com.br 
ensino seria como uma espécie das atuais agências reguladoras, como órgão máximo da administração federal da educação.

Palavras-chave: Oficialização e desoficialização. Reforma de ensino no Brasil. Educação pública e privada.

The LOSS OF OFFICIAL STATUS OF TEACHING IN BRAZIL: THE RivadÁVIA REFORM

ABSTRACT: The Rivadávia Reform was declared in 1911 by the Ministry of Justice Rivadávia Corrêa and former president Hermes da Fonseca, both of then Positivism followers. Between 1911 and 1915, the reform aimed the end of the education official status. Following a possible interpretation of 1891 Constitution text, the government settles down that secondary and superior institutions would loose their official standing and would become independent autonomic entities, with freedom to officially validate certificates and degrees. Free learning would be the best method to avoid poor teaching, bad facilities and uncontrolled degree emissions. A Superior Council of Teaching was created to be in charge of the transition between the former situation and the next context.

Key words: Brazil teaching reform officialization. Public and private teaching. End of officialization.

D

urante a Constituinte de 1890-1891 houve um intenso debate em torno da procedência do ensino oficial até então existente no país. Entenda-se por ensino oficial aquele criado e mantido pelos poderes públicos, aos quais também pertence a titularidade privativa da chancela dos certificados e diplomas. Os primeiros atestam a conclusão de um curso escolar, o segundo é condição para o exercício de profissões regulamentadas. Goza das prerrogativas do ensino oficial aquele ofertado pela iniciativa privada autorizada a fazê-lo, tendo em vista a liberdade de ensino. Por consequência, pode-se dizer que o ensino oferecido pela iniciativa privada, quando autorizado, tem o valor do ensino oficial. ${ }^{1}$

O debate na Constituinte trouxe à tona alguns parlamentares identificados com o positivismo, para quem o ensino oficial como ensino outorgado pelo Estado corre o risco de se constituir em uma religião 
oficial, já que as forças intelectuais ou poder espiritual devem fazer circular o conhecimento científico a partir da sociedade civil, irrigando as forças materiais ou poder material. Daí a defesa da desoficialização, sobretudo no ensino secundário e superior. Por meio da plena liberdade espiritual chegar-se-ia, de modo progressivo, à hegemonia do positivismo no seu estágio superior: a convergência entre ciência e moral. Para os positivistas, o governo não possui meios independentes, morais e intelectuais, de convencer o capital e o trabalho a se incorporarem aos ditames da sociedade moderna. Entre outros aspectos dessa defesa, se situa a defesa preferencial da educação primária a ser dada no âmbito doméstico, sob a égide do papel da mulher e mãe. Nesse último ponto, a defesa positivista foi secundada pelo catolicismo, ainda que sob outro prisma epistemológico.

Por outro lado, os parlamentares constituintes, em sua maioria, decidiram pela manutenção do ensino oficial sem proibir a presença e a oferta do ensino privado. Ou seja, não houve nem monopólio estatal, nem a abdicação da titularidade privativa do Estado em relação ao valor dos certificados e dos diplomas. Contudo, essa defesa do ensino oficial não queria se ver confundida com a centralização imperial, ainda que na educação houvesse tanto uma descentralização, desde 1834, quanto barreiras para uma liberdade de ensino para além do catolicismo como religião oficial do Estado.

Essa titularidade privativa do Estado, por sua vez, condicionou a equiparação dos certificados e diplomas emitidos pela iniciativa privada ao cumprimento de determinadas condiçōes. Contudo, a República não tolheu essa iniciativa nem por parte de correntes laicas, nem por grupos confessionais.

A solução dada pela Constituinte em acolher tanto o ensino oficial quanto o ensino ofertado em cursos livres não abrandou o ímpeto de grupos e parlamentares ligados ao positivismo na vontade de desoficializar o ensino. Afinal, ao lado disso, a Constituição também afirmou o livre exercício das profissōes (cf. Cury, 2001).

Ao bater-se pela disseminação da ciência como forma de elevar a população de "estados mais atrasados para os mais elevados", ao defender que o saber é a fonte original do poder, o positivismo teria na educação em geral e na escolar em particular um de seus campos mais importantes de atuação. Tal é, então, a defesa do ensino livre, do caráter 
laico do ensino ministrado nas escolas e da importância da família na educação inicial. ${ }^{2}$

Para tanto, líderes positivistas buscaram influenciar vários aspectos do ordenamento jurídico nacional, seja em constituições e leis, seja em decretos ordenadores da vida nacional, aí incluídas as várias reformas educacionais na República nascente.

Benjamin Constant, ministro da Secretaria da Instrução Pública, Correios e Telégrafos, empreendeu a Reforma da Instrução Pública Primária e Secundária do Distrito Federal que deveria modelar para o país. Não se pode negar a influência da ordenação curricular dessa Reforma segundo a classificação das ciências de Augusto Comte, ainda que de forma não ortodoxa. Mas a Reforma, em seu plano curricular, seria o critério para qualquer tipo de equiparação, face aos seus similares estaduais ou livres, o que contrariava a ala ortodoxa do positivismo. Assim, manteve-se a garantia do ensino oficial face ao ensino livre, a distinção de escolas primárias para cada sexo e a importância da família, em cujo seio o ensino poderia ser ministrado. Ministrado em escolas oficiais, o ensino primário seria gratuito e laico. E o ensino livre coexistiria com o oficial, mas sob a égide desse último, no qual se desenhava um Estado educador. Sobre esse assunto, comentando o pensamento comteano e sua influência no Brasil, diz Bosi (2007, p. 219):

A escola primária gratuita é assim projetada no quadro mais amplo da educação popular, que Comte prefere chamar "proletária", na verdade a única de que os governantes deveriam se encarregar, delegando aos diferentes grupos sociais quais quer projetos de ensino universitário. Que o Estado cuide da educação fundamental do povo e se abstenha de concorrer para a proliferação de falsos doutores, esses portadores de diplomas que engrossam as fileiras da pedantocracia.

A reforma de 1901, de Epitácio Pessoa, buscou tornar exequível aquela gerada por Benjamin Constant, considerada adequada, porém em seus delineamentos genéricos.

A oportunidade para levar adiante essa vontade de desoficialização se deu quando o Marechal Hermes da Fonseca (1855-1923) assumiu o poder presidencial. ${ }^{3}$ Vitorioso nas eleições disputadas com Rui Barbosa e sua campanha civilista, tomou posse como presidente da República com mandato entre 1910-1914. Hermes da Fonseca, tendo sido aluno 
de Benjamin Constant e fundador do Clube Republicano do Círculo Militar, aderiu ao ideário positivista. No governo, praticou a chamada política salvacionista, inspirada em Pinheiro Machado (1855-1915), de cujo conteúdo centralizador e unitarista contava a restauração do prestígio e da força dos militares no âmbito da esfera pública, intervindo nos Estados para fazer face às suas oligarquias regionais presentes nos governos estaduais. Destacou-se por uma política externa de aproximação com os Estados Unidos da América e, internamente, teve de enfrentar a Revolta da Chibata (1910) e a Campanha do Contestado (19121915). Deu continuidade à construção de ferrovias e à implantação de escolas técnico-profissionais. ${ }^{4}$ Almeida Jr. (1953, p. 77) assinala:

Ao assumir o governo da República, havia o Marechal Hermes da Fonseca dito horrores do ensino superior: "o mercantilismo chegou ao auge"; "as escolas superiores são tomadas de assalto por uma multidão de incapazes"; desceu o ensino a tal descrédito que, "ou se faz a sua reforma radical, ou preferível será aboli-lo de uma vez”.

$\mathrm{Na}$ composição de seu Ministério, defendendo em seu plano de governo uma liberal organização do ensino, Hermes da Fonseca chamou para titular da pasta da Justiça e Negócios Interiores seu conterrâneo Rivadávia Cunha Corrêa (1866-1920). Formado em Direito

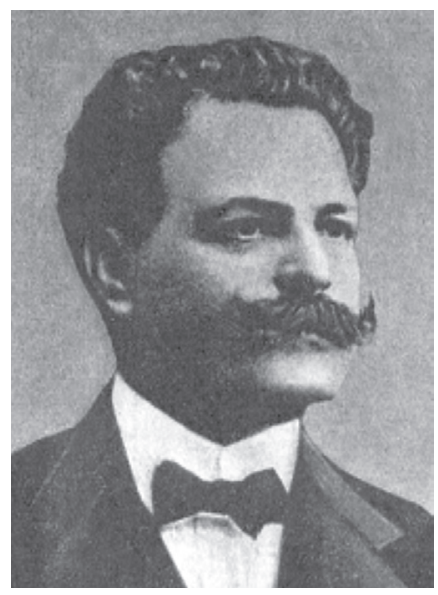

Ministro Rivadávia Corrêa 
pela Faculdade de Direito do Largo de São Francisco (São Paulo), também ele era positivista, tendo ocupado muitos cargos eletivos. Foi deputado estadual, federal em vários mandatos, senador pelo Rio Grande do Sul, foi prefeito do Distrito Federal, ministro da Fazenda e ministro da pasta que se ocupava da Educação.

Como a via da desoficialização, pela via parlamentar, fracassara, a sua viabilidade teria lugar pelo Poder Executivo. Comenta Nunes (1962, p. 96):

Contra o sistema tradicional vigente, insurgiu-se, de maneira violenta, o ministro Rivadávia Corrêa, com a Lei Orgânica de 1911. Levando o liberalismo político às últimas consequências, dentro do positivismo ortodoxo, resolveu retirar do Estado a interferência no setor educacional, estabelecendo o ensino livre. Sem as peias oficiais, poderia, julgava ele, o ensino desenvolver-se segundo as necessidades imediatas do Brasil.

Ou nos termos de Almeida Jr. (1953, p. 77):

Aparece daí a Reforma Rivadávia. Vem envolvida na roupagem compósita do liberalismo político e do positivismo ortodoxo, e arrasta o Estado, francamente, para o caminho da abstenção. Não se fiscalizam as escolas; não há exames oficiais; entra em eclipse a prova de capacidade para o exercício profissional.

A ânsia pela liberdade de ensino, defendida por vários próceres laicos e religiosos desde o Império, e a penetração do ideário positivista no governo central são alguns dos condicionantes por meio dos quais a Câmara e o Senado, pela emenda n. 118, de 12 de dezembro de 1910, relativa ao projeto orçamentário da União, autorizam o Presidente da República a reformar a instrução superior e secundária mantida pela União, dando sob conveniente fiscalização, sem privilégio de qualquer espécie:

I - Aos institutos de ensino superior: a) personalidade jurídica e competência para administrar seus patrimônios, lançar taxas de matrícula e de exame, e mais emolumentos por diplomas e certidões... b) completa liberdade de organização dos programas dos respectivos cursos, nas condições de matrícula, exigindo exame de admissão para o ingresso em seus cursos...

II - Aos institutos de ensino secundário: a) a faculdade conferida na letra a, do número I; b) no seu ensino um caráter prático, libertando-o da 
condição subalterna de curso preparatório do ensino superior; c) autonomia em sua disciplina.

Importante a se assinalar é que, para tal, o poder público se apóia no artigo 30, inciso II da lei n. 2.356 de 1911, como ato do poder legislativo, e que diz textualmente:

I - A reorganizar a Secretaria de Estado da Justiça e Negócios Interiores, bem como as repartiçôes dependentes da mesma secretaria e a Força Policial do Distrito Federal, abrindo para isto os necessários créditos assim como para execução das reformas autorizadas nesse artigo:

II - A reformar a instrução superior e secundária mantida pela União, dando, sob conveniente fiscalização, sem privilégio de qualquer espécie:

Aos institutos de ensino superior: a) personalidade jurídica e competência para administrar os seus patrimônios, lançar taxas de matrícula e de exame e mais emolumentos por diplomas e certidōes, arrecadando todas as quantias para provimento de sua economia, não podendo também sem anuência do Governo Federal alienar bens; b) completa liberdade na organização dos programas dos respectivos cursos, nas condições de matrícula, exigindo o exame de admissão para o ingresso em seus cursos, no regime de exames e disciplina escolar.

Aos institutos de ensino secundário: a) a faculdade conferida letra a anterior aos institutos de ensino superior; b) ao seu ensino um caráter prático, libertando-o da condição subalterna de curso preparatório do ensino superior; c) autonomia em sua disciplina.

É dessa autorização e dessa lei, ambas da maioria governamental no Congresso, que se tem a origem próxima do Decreto n. 8.659, de 5 de abril de 1911, denominada Lei Orgânica do Ensino Superior e do Fundamental da República. Como de praxe, precede à lei uma Exposição de Motivos. A revogação da lei anterior: a de Epitácio Pessoa, consta dessa Lei. Inspirada na doutrina positivista, esse Decreto será o primeiro documento em que a desoficialização do ensino público é explicitamente assumida.

Na Exposição de Motivos, Rivadávia procura justificar sua proposta como se ela fosse o coroamento de uma sequência progressiva das Reformas de 1879, de 1891 e de 1901. Segundo ele, o que está se delineando em curvas mais ou menos sinuosas é o fio de liberdade até se chegar à plena liberdade espiritual na Reforma (in: Moacyr, 1942, p. 9). Assim, 
em 1879, Rivadávia aponta a emergência do ensino livre como substituto do ensino obrigatório. Para ele, naquele momento, o ensino livre foi a via da emancipação das consciências pelo abolicionismo e republicanismo contra "a passiva obediência às doutrinas dos mestres" (idem, ibid., p. 10). A Reforma de 1891, para o seu autor, ao consagrar a equiparação dos estabelecimentos particulares aos oficiais, "trouxe a confirmação de que não é o monopólio dos estabelecimentos oficiais, como já não era dos seus lentes, a distribuição do ensino" (p. 11). A Reforma de 1901, ainda que tenha sido desviada de sua proposta, acabou por transformar "a liberdade de frequência em liberdade de vadiar” (p. 11), propiciando a fuga dos estudantes das salas de aula. Contudo, Rivadávia acentua, nessa Reforma, a importância do estabelecimento da "livre docência que significa, nada mais, nada menos do que a permissão ao aluno para escolher o seu mestre e a garantia a qualquer cidadão habilitado para lecionar no recinto dos estabelecimentos oficiais" (p. 11-12). Segundo ele: "A presente organização assinala e tem em vista uma suave e natural passagem da vigente oficialização do ensino para a sua completa desoficialização, corolário fundamental da liberdade profissional, consagrado na Constituição da República” (p. 14).

Com efeito, a sustentação desse ponto de vista se apóia no texto constitucional de 24 de fevereiro de 1891, cujo artigo 72, $\$ 24$, diz que "é garantido o livre exercício de qualquer profissão moral, intelectual e industrial”. Associa-se, a esse parágrafo, o $\$ 12$ sobre a livre manifestação de pensamento e o $\$ 8^{\circ}$ sobre a liberdade de associação e de reunião. Contudo, rigorosamente falando, a Lei Orgânica não poderia avançar sobre a autonomia dos Estados nessa matéria.

Cumpre agora repassar alguns artigos desse longo decreto de 140 artigos, junto aos quais se colocarão alguns comentários feitos por uma consultoria e assumidos pelo próprio autor do Decreto, em publicação de 1912 (cf. Moacyr, 1942).

$\mathrm{Na}$ Introdução ao livro que traz a Lei Orgânica e os comentários que a acompanha, artigo por artigo, o autor assim se expressa: "Desandando, em boa hora, as veredas percorridas pelos seus antecessores, o Sr. RIVADÁVIA CORRÊA abandonou a terapêutica paliativa, tão cômoda quão ineficaz, e enveredou francamente pelo largo caminho da reconstrução (...)” (p. VIII). 
Segundo o mesmo autor, pela Lei perpassa, "consoante as tendências da civilização, um sopro de bem entendida liberdade. Porque se não confunde com o amorfismo das outras (...) e embebida das tradições de puro liberalismo, que animam as instituiçỗes republicanas (...) sabe o que quer e quer o que sabe (...)" (p. vIII).

Atacando a situação existente na educação como um todo, especialmente a existência de modelos oficiais de ensino, afirma que os laços que uniam o ensino secundário com o superior foram cortados.

O ensino superior sofria em dobro. Vasadouro de colégios, onde a mocidade desaprende a estudar (...) esteriliza-se na triste missão de favonear a vaidade das classes favorecidas da fortuna, concorrendo anualmente com a falange de bacharéis e doutores, que são a vergonha e o atraso de uma época (...). [A lei orgânica] Extinguiu os diplomas - miragem perturbadora da burguesia fátua - e eliminou (...) as regalias acadêmicas. (p. XI)

O ensino livre seria o antídoto dos maus catedráticos, da busca desenfreada pelos diplomas e não pela ciência, fraudes e instalaçôes precárias. Referindo-se à autonomia dos institutos e do corpo docente, ele afirma (p. XI): "A autonomia não se restringiu a uma vantagem exclusiva das congregaçóes (...) é também um direito do professor, quanto ao sistema e método do ensino, que são de sua competência e em que a iniciativa individual pode dar fecundos resultados".

Rivadávia, assim, vê, no compromisso com a ciência e no senso de dever, a face reversa da liberdade: a responsabilidade.

Passando agora aos artigos da Lei Orgânica:

Art. $1^{\circ}-\mathrm{A}$ instrucção superior e fundamental, diffundidas pelos institutos creados pela União, não gosarão de privilegio de qualquer especie.

Aqui está a desoficialização. É o fim do Estado Educador, é a famosa defesa positivista de que o poder espiritual não pode ser tutelado pelo poder temporal dos governos. O diploma era considerado um ato oficial de governo cujo privilégio seria o de ser oficial e de ser o critério para a equiparação existente até então desde o Império.

Nos termos dos comentários apensos ao livro do autor, se diz: "Este art., pois, consagra o princípio da liberdade profissional" (p. 3). No relatório encaminhado ao Presidente Hermes da Fonseca para efeito de assinatura da Lei, diz Rivadávia (p. 2): 
Daí a abolição dos privilégios concedidos a institutos de instrução para que só eles ministrem o ensino fundamental e superior, daí a eliminação dos privilégios escolares, dos diplomas e dos títulos, deixando que cada qual procure o estudo pelo que ele tem de alto e digno e não com o intuito subalterno da conquista de um pergaminho que lhe dê descabidas e injustas prerrogativas na competição social.

O apoio para tal estaria no artigo $72, \$ 24$ da Constituição, associado à Lei n. 2.536, de 31 de dezembro de 1910. O exercício profissional, dentro da lógica da Lei, deveria ser controlado pela população, discernindo entre os bons e maus profissionais.

Art. $2^{\circ}$ - Os institutos, até agora subordinados ao Ministerio do Interior, serão, de ora em diante, considerados corporações autonomas, tanto do ponto de vista didactico, como do administrativo.

Corporação autônoma é uma personalidade jurídica que significa o gozo de uma autonomia administrativa e didática e, no caso, nesses campos, não mais subordinada ao Ministério do Interior. Nos termos do comentário: "Acreditando que a intervenção do Estado nas coisas do ensino foi sempre perturbadora e representou um papel principal no descrédito dos institutos, o legislador afastou-a de modo claro e positivo".

Art. $3^{\circ}-$ Aos institutos federaes de ensino superior e fundamental é attribuida, como ás corporaçōes de mão morta, personalidade juridica, para receberem doaçóes, legados ou outros bens e administrarem seus patrimonios, não podendo, comtudo, sem autorização do Governo, aliena-los.

A nova personalidade jurídica ganhava a possibilidade de gerir seus próprios recursos, seu patrimônio, advindos do Estado, mas não lhe cabia vendê-los ou dispor dos mesmos sob forma de alienação.

Nos termos do comentário, trata-se de aliviar os cofres públicos desse ônus e implicar os institutos na busca de recursos próprios, sobretudo de doações. A referência à Alemanha e aos Estados Unidos é feita como exemplo modelar da nova personalidade jurídica.

Art. $4^{\circ}-$ Nas faculdades de medicina do Rio de Janeiro e da Bahia será ministrada cultura medica; nas faculdades de direito de $S$. Paulo e de Pernambuco, a das lettras juridicas; na Escola Polytechnica do Rio de Janeiro, a de mathematica superior e engenharia, com todas as suas 
modalidades; no Collegio Pedro II se ensinarão as disciplinas do curso fundamental, com o seu desenvolvimento litterario e scientifico.

Em um primeiro momento, o governo estabelecia um currículo, mas que, devido ao artigo $2^{\circ}$, poderia ser modificado.

Art. $5^{\circ}$ - O Conselho Superior do Ensino, creado pela presente lei, substituirá a funcção fiscal do Estado; estabelecerá as ligações necessarias e imprescindiveis no regimen de transição que vae da officialização completa do ensino, ora vigente, à sua total independencia futura, entre a União e os estabelecimentos de ensino.

Fica claro que o Ministério do Interior entrega ao Conselho a tarefa de fazer a transição da oficialização completa à sua total independência futura. É como se tolerasse o ensino oficial, posto em regime de extinção, por ser ruim e incompetente, até que ele desaparecesse por completo. O Conselho seria como que uma espécie do que hoje denominamos Agência Reguladora, como órgão máximo da administração federal da educação. Como se pode ver no artigo 11, esse Conselho tinha um caráter deliberativo e consultivo. O comentarista aproxima-o com o Conselho de Educação dos Estados Unidos, de 1887, e aponta que este é o modo pelo qual o Estado obedece aos ditames da Constituição, não sendo indiferente ao ensino. Mas sem admitir "o ensino como função própria do Estado” (p. 7), cabe-lhe apenas fiscalizar os recursos que póe nesses institutos.

Em sessão do Conselho Nacional de Educação, datada de 14 de junho de 1949, o Presidente Cesário de Andrade fez uma referência à atuação desse Conselho Superior de Ensino (CSE), criado em 1911: "Quem se der ao trabalho de compulsar os anais do Conselho Superior do Ensino da época poderá avaliar a tarefa ingente em que este se empenhou, no afã de corrigir os erros que foram cometidos, malgrado a sua ação vigilante, durante a vigência daquela lei” (in: Bordignon, 2005b).

Art. $6^{\circ}$ - Pela completa autonomia didactica que lhes é conferida, cabe aos institutos a organização dos programmas de seus cursos, devendo os do Collegio Pedro II revestir-se de caracter pratico e libertar-se da condição subalterna de meio preparatorio para as academias.

$\mathrm{O}$ artigo fala por si em matéria de autonomia didática: completa autonomia didática. Já o Colégio Pedro II deveria conter, em seus 
programas, conteúdos que visassem um sentido profissionalizante como uma forma de conter o que a crítica denominava, pejorativamente, de bacharelismo (ver o teor do artigo 138). Leia-se o comentarista:

Os institutos ficam, pois, livres das incursões do Governo em matéria tão delicada que só por técnicos deve ser examinada, como seja a diretriz dada aos estudos. $\mathrm{O}$ ensino fundamental nobilitou-se e ganhou situação própria; não servirá mais como trampolim para o assalto às academias. $\mathrm{O}$ tempo demonstrará as vantagens que o amor às letras e às ciências adquirirá com a medida. Uma delas, a extinção da indústria dos colégios equiparados, não será certamente a menor. (p. 8)

Comentando essa passagem, Marques Jr. (1967. p. 245) conclui: "Assim, pelo regime de 1911, as escolas estaduais e particulares independeriam de autorização federal para o seu funcionamento, assim como não sofreriam qualquer interferência fiscalizadora por parte do Governo da Uniāo”.

Art. 11 - Os institutos a que se refere esta lei ficarão sob a fiscalização de um Conselho deliberativo e consultivo, com sede na Capital da Republica e funccionando no edificio de um delles.

\section{Segue o comentário:}

Urgia a formação de um aparelho destinado ao estudo dos problemas de ensino, essencialmente técnicos, e que por técnicos devem, portanto, ser resolvidos. A função deliberativa, consultiva e fiscalizadora do Conselho corrigirá os males oriundos das incertezas da praxe, sotoposta, até agora, ao arbítrio dos amanuenses e diretores (...). É o último elo de uma cadeia que começa na liberdade de estudar quem quiser e ensinar quem puder, e termina na autonomia completa dos institutos, baseada na convergência dos esforços de cada uma. (p. 13)

Art. 31 - A corporação docente de cada instituto de ensino superior será composta: a) de professores ordinários; b) de professores extraordinarios effectivos; c) de professores extraordinarios honorarios; d) de mestres; e) de livres docentes.

Paragrapho unico. A do Collegio Pedro II será formada simplesmente pelos professores ordinários e pelos mestres.

Segundo o comentarista, diz ele: 
Esse artigo substitui as antigas denominações dos membros do magistério, desaparecendo os lentes catedráticos, os lentes substitutos, os professores de aulas. Os livre docentes, que surgem com este Art., assim como os professores extraordinários honorários não têm correspondência no Código de Ensino de 1901. (p. 36)

Art. 65 - Para concessão da matricula, o candidato passará por exame que habilite a um juizo de conjuncto sobre o seu desenvolvimento intellectual e capacidade para emprehender efficazmente o estudo das materias que constituem o ensino da faculdade.

$\$ \mathrm{I}-\mathrm{O}$ exame de admissão a que se refere este artigo constará de prova escripta em vernaculo, que revele a cultura mental que se quer verificar e de uma prova oral sobre línguas e sciencias;

A Lei Orgânica cria o exame de admissão, mais tarde denominado vestibular. Não se exige uma escolaridade prévia como aquela do ensino oficial e existente nas escolas equiparadas ao modelo do Pedro II. $\mathrm{O}$ vestibular é face da autonomia dos institutos. Veja-se o comentário do autor:

O exame de admissão não tem por fim verificar o valor do curso fundamental. Escolhe, entre os candidatos à matrícula nos cursos superiores, os mais bem equilibrados e com um desenvolvimento intelectual capaz de suportar o prosseguimento dos estudos técnicos. Não é um exame minucioso, um exame de preparatórios por atacado. (p. 71)

Art. 71 - A qualquer alumno é permittido transferir, no fim de cada periodo lectivo, a matricula para qualquer faculdade do paiz, mediante requerimento ao director, que autorizar a transferência na respectiva caderneta.

\section{As transferências foram facilitadas.}

Art. 74 - As matérias dos institutos serão distribuídas e lecionadas por séries, obedecendo a sua reunião e gradação ao nexo científico que ligarem, indo do mais simples ao mais complexo.

Além da seriação, a Lei estabelece a regra geral do sistema de classificação das ciências, de acordo com os princípios do positivismo.

Art. - 82. A policia academica tem por fim manter no seio da corporação academica a ordem e a moral. 
Rivadávia propugna, no interior dos institutos, a disciplina, o comparecimento controlado às aulas, a devida seriação e a obrigatoriedade dos períodos letivos. E os professores deveriam seguir o programa planejado e aprovado pela Congregação. E os livre-docentes, desde que aprovados pela instituição, poderiam oferecer cursos privados que merecerem a confiança dos estudantes.

Art. 124 - O estudante que terminar as provas escolares receberá, mediante o pagamento da taxa respectiva, o certificado que lhe competir, de accôrdo com os regulamentos especiaes.

Acabaram-se os diplomas. Agora eles foram substituídos por certificados. Um diploma, de modo geral e pela legislação precedente, é profissionalizante e tem valor oficial. Já um certificado é um atestado de conclusão de um curso sem os privilégios de um diploma. ${ }^{5}$ Segue o comentário:

Durante a propaganda que precedeu à reforma do ensino, a caça ao diploma foi sempre apontada como um dos elementos de descrédito. $\mathrm{O}$ ensino fundamental e o ensino técnico foram abastardados, porque miravam exclusivamente a aquisição do pergaminho de bacharel e de doutor. A doutorice constituiu o lado ridículo das instituições brasileiras (...). Ora, o feitio especial da doutorice é desatender às realidades, tudo conceber a priori e querer organizar e reger o mundo pelas regras dos compêndios (...). Os resultados foram a avalanche de matrículas nos cursos superiores e as imensas levas anuais de doutores e bacharéis. Tais diplomas, pela presente organização, são substituídos por modestos e democráticos certificados, atestando a assistência e o aproveitamento nos respectivos cursos. (p. 102 e 104)

Art. 126 - Ao corpo docente e ao pessoal administrativo de cada um dos estabelecimentos que passam a ser emancipados, o Governo garantirá as regalias moraes e materiaes a que têm direito pelas leis até agora em vigor.

O governo não se ausentaria de subsidiar o orçamento desses seus institutos. Mas nem ele precisaria ser dominante e nem poderia abdicar de buscar outras fontes de recursos. Esse artigo se completa com o $\$$ único do artigo 127.

Paragrapho único. Das subvenções votadas pelo Congresso Nacional entregues aos institutos de ensino será deduzida a parte referente aos 
actuaes docentes e funccionarios que continuarão a receber os seus vencimentos no Thesouro Nacional.

É como se dissesse: mantenham-se os direitos adquiridos dos atuais funcionários. Dos próximos, as coisas poderiam ser diferentes.

Art. 127 - Os docentes e funccionarios, nomeados na vigencia do regimen escolar creado pela presente lei, receberão os seus vencimentos na thesouraria do instituto a que pertencerem.

\author{
É uma indicação de um regime diferenciado para os novos con- \\ tratados.
}

Paragrapho único. Para este effeito e demais despezas, o Governo entregará aos institutos de ensino, emquanto os patrimonios delles não bastarem à satisfação das necessidades materiaes e pedagogicas, e sob o titulo de subvençãao, as quantias necessarias e votadas em lei.

Art. 138 - As Congregaçôes dos institutos de ensino, por força da autonomia administrativa e didactica que lhes é garantida pela presente lei, ficam com a liberdade de modificar ou reformar as disposiçôes regulamentares e as inherentes á intima economia delles.

\title{
Comentando:
}

O ensino oficial desmoralizou-se com a série ininterrupta de reformas precipitadas. O art., combinado com as letras b, c e f, do art. 60 e com o art. 2, impede, para sempre, a interferência do público poder na instrução fundamental e superior. (p. 123)

Art. 139 - Aquelle ou aquelles dos institutos comprehendidos no art. $4^{\circ}$ que, dispondo de recursos proprios e sufficientes, prescindirem de subvenção do Governo, ficarão, por esse facto, isentos de toda e qualquer dependencia ou fiscalização official, mediata ou immediata.

Comentário sem comentários: "O art. 139 promove a desoficialização do ensino, velho sonho dos republicanos”. Assim, aos institutos cabe a autonomia quase que total de suas açóes.

A desoficialização propiciada pela Reforma Rivadávia possibilitou a abertura de escolas de todos os tipos. Surgiram algumas escolas sérias, mas, sob o impacto de um mercado propício, surgiram também as famosas "academias elétricas". Como assevera Nagle (1974, p. 145): 
Diante das prescriçôes da Lei Orgânica, desaparece a necessidade de um curso secundário modelo, papel que vinha exercendo o Ginásio Nacional. O ensino oficial, uniforme, do sistema de 1901 cede lugar, então, a um ensino livre, diversificado e flexível, a realizar-se em estabelecimentos autônomos. Mas, em franco desacordo com as condiçōes do meio escolar brasileiro, as medidas desoficializadoras de 1911 provocam "grande balbúrdia na vida escolar”, e nova reforma se impõe.

\section{Ou nos termos de Azevedo (1963, p. 628):}

A chamada lei orgânica do ensino (decreto de 5 de abril de 1911), refletindo a orientação positivista dominante no Rio Grande do Sul, instituiu o regime do ensino livre subtraindo ao Estado a interferência no domínio da Educação, estatuiu o exame vestibular, suprimiu os diplomas e, promulgando a autonomia das Congregaçōes, despojou o governo ao direito de se imiscuir na economia interna dos institutos superiores. Longe de a refrear, contribuiu essa reforma para acentuar a degradação a que descera o ensino secundário, quer sob o regime dos exames parcelados, quer sob a vigência dos exames de madureza, quer sob o sistema de equiparaçôes.

Também nos termos de Almeida Jr. (1953, p. 77):

Durou pouco a experiência, - um quatriênio apenas. Mas êsse breve período bastou para evidenciar que, em lugar de curar os males denunciados pelo Presidente da República, a audaciosa inovação do seu Ministro da Justiça os agravara. Fôra "varrido por um tufăo" o ensino secundário, - disse a Comissão de Instrução Pública da Câmara, pois não o estimulavam ao esfôrço e à seriedade os sumaríssimos exames vestibulares das Academias. Improvisaram-se Universidades; brotaram escolas superiores como cogumelos; proliferou o ensino universitário por correspondência; fez-se dos títulos acadêmicos (que continuavam a valer, a despeito da lei) objeto do mais vergonhoso comércio; tanto que diplomas de médicos, advogados ou engenheiros, diplomas de $60 \$ 000$, como vieram a ser conhecidos (porque era êsse, realmente, o seu preço) - inundaram durante dois ou três decênios o mercado profissional do País e das Repúblicas sul-americanas.

Também se pode ler em Silva (1969, p. 272-273): “Os resultados da reforma Rivadávia foram, portanto, desastrosos. (...) o fato incontrovertível foi que a desoficialização de um e a do outro grau de ensino mutuamente se reforçaram para acentuar o estado de decadência da instrução". 
Essa liberdade de ensino fez com que muitos estados vissem nesse recuo do Estado federal a via pela qual pudessem estabelecer suas universidades, como a livre de Manaus (1909), a de São Paulo (1911) e a do Paraná (1912). ${ }^{6}$ E tais escolas não necessitavam mais da fiscalização exercida pela União. Também, esse recuo permitiu a proliferação de escolas vinculadas ao ensino privado, de tal modo que à desoficialização se seguiu uma verdadeira privatização do ensino e uma grande dispersão formativa. ${ }^{7}$

Ora, esta face expansionista e flexibilização avant la lettre, dada a dispersão e desqualificação havidas na abertura de escolas àquela época, com teor mercantilista de que também se recobriu a Reforma Rivadávia, determinaram o retorno do poder de Estado na autorização e controle do ensino superior, por meio da reinstauração da oficialização inclusive com o retorno do instituto da equiparação.

Tanto é assim que o Congresso autorizou o governo Wenceslau Braz a rever o Decreto Rivadávia. ${ }^{8}$ Dodsworth (1968, p. 128), assim reproduz essa autorização:

(...) rever o decreto n. 8.569, de 5 de abril de 1911, para o fim de corrigir as falhas e senões que a experiência mostrou existir na atual organização do ensino, providenciando no sentido de um melhor lançamento e distribuição de taxas e emolumentos escolares, assegurada a personalidade jurídica, e autonomia didática, administrativa e disciplinar dos estabelecimentos mantido pela União, podendo estabelecer normas que lhe parecerem mais convenientes aos interesses do mesmo ensino em toda a República.

(...) Enquanto o Congresso Nacional não revogar as leis que exigem diplomas aos candidatos a várias funções públicas, o Poder Executivo, ouvido o Conselho Superior de Ensino, organizará a lista das Universidades, Faculdade de Direito, Medicina, Engenharia e outras cujos alunos poderão ser aproveitados depois de formados no serviço federal.

Poderá, outrossim, excluir da referida lista aquelas Universidades ou Academias e Faculdades e Escolas que, após informação do mesmo Conselho, verifique não terem adquirido idoneidade ou terem perdido aquela de que gozavam.

A Lei n. 2.924, de 5 de janeiro de 1915, diz em seu artigo 30:

Fica o Governo autorizado: a) a rever o Decreto n. 8.659, de 4 de abril de 1911, para o fim de corrigir as falhas e senões que a experiência mostrou 
existirem na atual organização do ensino, providenciando no sentido de um melhor lançamento e distribuição de taxas e emolumentos escolares, assegurada a personalidade jurídica, a autonomia didática, administrativa e disciplinar dos estabelecimentos da instrução mantidos pela União, podendo estabelecer as normas que lhe parecerem mais convenientes aos interesses do mesmo ensino em toda a República.

No mesmo livro, Dodsworth (1968) reproduz um comentário de José Bernardino Paranhos da Silva, diretor do internato do Colégio Pedro II, que chama a Reforma Rivadávia de infeliz e assevera que o Decreto n. 11.530 de 1915 "revogou a desoficialização tentada pela lei orgânica, restabelecendo a ação imediata da União no ensino superior e secundário".

O Decreto n. 11.530, de 18 de março de 1915, assinado pelo presidente Wenceslau Braz e por Carlos Maximiliano, ministro da Justiça e Negócios Interiores, precedido de uma Exposição de Motivos, "reorganiza o ensino secundário e o superior na República”. Por ele o Ministro da Justiça e dos Negócios Interiores volta a homologar certas decisōes do Conselho Superior de Ensino, o adjetivo oficial retorna para junto dos institutos mantidos pela União, restaura-se o registro de diplomas, impóe-se a inspeção federal sobre os institutos, bem como a figura da concessão para efeito de equiparação para as instituições particulares que a solicitarem, exceto as que tiverem intento de lucro ou de propaganda filosófica ou religiosa. A equiparação não seria atribuída também a institutos em cidades com menos de 100 mil habitantes (exceto capitais) ou se houvessem mais de duas academias de Direito, Engenharia e Medicina em cada estado. O CSE é reduzido a órgão consultivo e fiscalizador, a matrícula no ensino superior teria como exigência adicional ao vestibular o certificado de aprovação no secundário. Com isso, reoficializa-se o ensino.

A iniciativa privada não perde a liberdade de atuação junto ao ensino, mas agora ela é denominada de academia e volta a ser regrada pelos institutos da concessão e da equiparação, sendo controlada e fiscalizada pelo CSE.

Contudo, pode-se dizer que a Reforma Rivadávia, com sua desoficialização, foi muito original e buscou, em base à concepção positivista, outro campo para o desenvolvimento da educação. Esse campo apontava para um Brasil em que a sociedade civil como um todo 
ainda era muito fraca e sujeita aos interesses de uns poucos. Com isso, o recuo do Estado e sua eventual saída significaram um campo livre para toda a sorte de inescrupulosos tomarem de assalto a educação.

Ficou a lição de que a saída ou o recuo do Estado em matéria de educação abre o campo para alguns setores sadios da sociedade civil. Mas, ao mesmo tempo, abre o flanco para transformar a educação, serviço público e bem público, em um serviço identificado com um bem qualquer, mercadoria vendável no mercado.

Em um texto de 1997, o autor das páginas aqui escritas se perguntava se, com o teor das diretrizes e bases da Lei n. 9.394/96, não era "lícito averiguar a hipótese de um retorno parcial e relativo à Reforma Rivadávia de 1911” (p. 99). Mais adiante, o mesmo texto apontava a aproximação com a Reforma de 1911 pela grande flexibilidade presente na lei, face à educação básica e à educação superior, ressalvadas a manutenção do ensino oficial, o caráter dos diplomas, a autorização de funcionamento e a avaliação de qualidade. E mesmo assim advertia, ainda em 1997:

Essa flexibilização corre, contudo, um sério risco: dadas as perversidades atávicas de nossos sistemas educacionais, aí considerados aspectos externos e internos à escola, ela pode servir como cortina de fumaça para uma precariedade destes sistemas e até mesmo como uma legitimação da mesma (...). O dever do Estado com a educação não pode ser diminuído com a flexibilidade, ao contrário, sua função clássica em atendê-la deve ser exigida e cobrada pelos outros poderes da democracia representativa e pela sociedade civil. Esta exigência se torna ainda mais significativa se atentarmos para os efeitos perversos e imponderáveis da globalização. (p. 101-102)

Coisa não muito diferente está na base da investida da Organização Mundial do Comércio (OMC), que pretende flexibilizar de tal modo o ensino superior do controle nacional e estatal que esta etapa do ensino ficaria colocada sob a égide preferencial do sistema contratual de mercado e, por aí, dos segmentos internacionais, de preferência pondo a avaliação, ou melhor, a certificação dessas escolas dentro dos padrōes da International Organization for Standartization (ISO), ${ }^{9}$ ou por um sistema de autorregulação.

Recebido em julho de 2009 e aprovado em agosto de 2009. 


\section{Notas}

1. Sobre os antecedentes de propostas de liberdade de ensino, cf. Marques Jr. $\left(1967,2^{\text {a }}\right.$ parte).

2. Considerado o Estado laico, interessante notar duas aproximaçōes entre o positivismo e o catolicismo. Ambos convergem para a educação doméstica, sob a figura da mãe e mestra e para a liberdade de ensino, mas sob concepçôes diferentes. Para o catolicismo, à época, retirar o Estado é necessário para ocupar a posição de quem detém verdades que só a Igreja Católica é capaz de ensinar. Para o positivismo, o Estado enquanto força temporal não possui distanciamento suficiente para acolher o desenvolvimento das forças espirituais na sociedade civil.

3. Sobre os projetos de descentralização e de desoficialização, inclusive no Império, cf. Marques Jr. (1967, p. 153-160).

4. É conhecida a inclinação do pensamento positivista pelo ensino técnico profissional. Como diz Bosi (2007, p. 20): "Desenvolvimento da indústria mais ensino técnico mais créditos públicos = conquista de mercados consumidores".

5. A Constituição do Rio Grande do Sul, de 14 de julho 1891, aboliu os chamados privilégios decorrentes de diplomas, abrindo o livre exercício profissional no Estado. A restrição advinha do necessário registro e da verificação da competência profissional (cf. art. $5^{\circ}$ e art. $6^{\circ}$ dessa Constituição)

6. Para a expansão no período, cf. Cunha (1980, p. 164-167).

7. Para conferir as críticas a essa Reforma, no Congresso Nacional, cf. Moacyr (1942, p. 55-69).

8. A oposição à Reforma Rivadávia pode ser conferida em Marques Jr. (1967, p. 275 ss). A abolição dos diplomas e da equiparação são dois pontos mais debatidos. Retomando os discursos de José Bonifácio, parlamentar por Minas, Marques Jr. Recupera um ponto da polêmica: a doutrina castilhista do RS, querendo se impor a 20 estados da União... Soares (2007, p. 367) afirma que Castilhos "tudo quanto não conseguiu introduzir na Constituição Federal, logrou transportar para a rio-grandense".

9. ISO é uma rede de certificação de qualidade, com a adesão de 156 países, que reúne institutos nacionais estandardizados. Criada em 1987, a partir da área de produtos industriais elétricos, visa analisar, consolidar e unificar as normas de produção exatamente quando o mercado de trocas se internacionalizou. Assim, o que se quer é um padrão internacional de qualidade. Este certificado é uma espécie de passaporte para mercados exigentes. Cada país pode contar com apenas um membro, sendo que o Secretariado Central, coordenador da rede, situa-se na Suíça. A ISO é uma ONG da qual participam membros advindos do setor privado, indicados por parceiros nacionais e membros pertencentes à estrutura governamental de cada país. O Brasil é representado pela Associação Brasileira de Normas Técnicas (ABNT).

\section{Referências}

\section{ALMEIDA JUNIOR, A.F. Enquanto se espera pelas diretrizes e bases. Disponível em: <http://ojs.c3sl.ufpr.br/ojs2/index.php/direito/article/ view/6167/4398>. Acesso em: 13 fev. 2009.}


AZEVEDO, F. A cultura brasileira: introdução ao estudo da cultura no Brasil. Brasília, DF: UnB, 1963.

BORDIGNON, G. Conselhos de Educação até 1961: relatório de pesquisa. Brasília, DF: UnB, 2005b. cap. 3. (mimeo.).

BOSI, A. O positivismo no Sul e a arqueologia do Estado-providência. In: Trindade, H. (Org.). O positivismo: teoria e prática. Porto Alegre: UFRGS, 2007.

CORRÊA, R. Lei Orgânica do Ensino Superior e do Fundamental na República: comentários precedidos de uma carta do exmo. Sr. Dr. Rivadávia Corrêa, Ministro do Interior. Rio de Janeiro: Francisco Alves, 1912.

CUNHA, L.A. A universidade temporã. Rio de Janeiro: Francisco Alves, 1980 .

CURY, C.R.J. A nova Lei de Diretrizes e Bases da Educação Nacional: uma reforma educacional? In: CuRY, C.R.J. et al. Medo à liberdade e compromisso democrático: LDB e Plano Nacional de Educação. São Paulo: Editora do Brasil, 1997.

CURY, C.R.J. Cidadania republicana e educação: governo provisório do Mal. Deodoro e Congresso Constituinte de 1890-1891. Rio de Janeiro: DP\&A, 2001.

CURY, C.R.J. O positivismo e a educação no Brasil. In: Martins, C.B. (Org.). Diálogos entre o Brasil e a França: formação e cooperação acadêmica. Recife: Massangana, 2005.

DODSWORTH, H. Cem anos de ensino secundário no Brasil (18261926). Rio de Janeiro: MEC/INEP, 1968.

LOPES, A.; MOTA, C.G. História do Brasil: uma interpretação. São Paulo: SENAC, 2008.

MARQUES JUNIOR, R. Política educacional republicana: o ciclo da desoficialização do ensino. 1967. Tese (Doutorado) - Faculdade de Filosofia Ciências e Letras, Universidade Estadual Paulista, Araraquara.

MOACYR, P. A instrução e a República. Rio de Janeiro: Imprensa Nacional, 1942. v. 4. 
A desoficialização do ensino no Brasil: a Reforma Rivadávia

NAGLE, J. Educação e sociedade na Primeira República. São Paulo: EDUSP, 1974.

NUNES, M.T. Ensino secundário e sociedade brasileira. Rio de Janeiro: ISEB, 1962.

SILVA, G.B. A educação secundária: perspectiva e teoria. Rio de Janeiro: Nacional, 1969.

SOARES, M.P. O positivismo no Rio Grande do Sul. In: Trindade, H. (Org.). O positivismo: teoria e prática. Porto Alegre: UfRGS, 2007. 